Article

\title{
Improved Milk Production from Supplementation of Swamp Buffalo with Molasses Nutrient Blocks Containing 10\% Urea
}

\author{
Peter Windsor ${ }^{1, * \mathbb{C}}$, Susan Martin ${ }^{2}$, Syseng Khounsy ${ }^{3}$, James Young ${ }^{1}$, Peter Thomson ${ }^{1} \mathbb{D}$ and Russell Bush ${ }^{1} \mathbb{C}$ \\ 1 Faculty of Science, The University of Sydney, Camden, NSW 2570, Australia; cowvet@gmail.com (J.Y.); \\ peter.thomson@sydney.edu.au (P.T.); russell.bush@sydney.edu.au (R.B.) \\ 2 Luang Prabang Buffalo Dairy, Luang Prabang, Laos; susmc@me.com \\ 3 Department of Livestock and Fisheries, Vientiane, Laos; s.khounsy@gmail.com \\ * Correspondence: peter.windsor@sydney.edu.au or peter.windsor57@gmail.com; Tel.: +61-02438983367
}

Citation: Windsor, P.; Martin, S.; Khounsy, S.; Young, J.; Thomson, P.; Bush, R. Improved Milk Production from Supplementation of Swamp Buffalo with Molasses Nutrient Blocks Containing 10\% Urea. Dairy 2021, 2, 90-103. https://doi.org/ 10.3390/dairy2010009

Received: 9 November 2020

Accepted: 27 January 2021

Published: 8 February 2021

Publisher's Note: MDPI stays neutral with regard to jurisdictional claims in published maps and institutional affiliations.

Copyright: (c) 2021 by the authors. Licensee MDPI, Basel, Switzerland. This article is an open access article distributed under the terms and conditions of the Creative Commons Attribution (CC BY) license (https:// creativecommons.org/licenses/by/ $4.0 /)$.

\begin{abstract}
Milk production from Asiatic swamp buffalo is a new enterprise in Laos. As yields are limited, provision of high-quality cow-calf molasses nutrient blocks containing 10\% urea (UMNB10) may improve productivity. A trial in a recently established commercial buffalo dairy examined dietary supplementation of lactating buffalo cows with UMNB10, with three groups of nine cows in mid-lactation randomly selected. Two groups received ad libitum access to UMBs with the remaining group free of block supplements. All animals were daily fed fresh Napier grass (30 kg), corn (750 gm), rice bran (1.45 kg), plus accessed fresh Mulatto grass. Daily milk production (DMP) and body condition score (BCS) were recorded for the 2 months of access to UMB. Average DMP for the two supplemented groups were 1.02 and $0.96 \mathrm{~L}$, compared to $0.78 \mathrm{~L}$ for the control group, suggesting improved milk productivity of 31 and $24 \%$ from accessing UMB. Partial budget analysis identified a strong incentive for use of the molasses blocks, with a net profit of USD 408 and USD 295 over a 30-day period for the supplemented groups. A multi-intervention livestock development strategy that includes a combination of nutritional and health interventions has been proposed for scale-out to assist smallholder livestock farming efficiency in developing countries. The use of high-quality molasses blocks may be a simple motivator for these communities to increase the efficiency of large ruminant production, improving rural livelihoods, food security, and potentially, reducing greenhouse gas emissions (GHGe) from ruminant-derived foods.
\end{abstract}

Keywords: Asiatic swamp buffalo (Bubalus bubalis); large ruminant production; Laos; dairy; molasses nutrient blocks; supplementation

\section{Introduction}

Livestock production accounts for approximately $40 \%$ of agricultural output in developed countries [1]. Advanced genetics, feeding systems, pasture improvements, animal health prevention and controls including improved biosecurity, plus other animal production management technologies, have reduced land requirements for livestock by about $20 \%$, producing a doubling of meat production over the last 40 years [1]. However, in subsistence agricultural systems, mainly involving smallholder farmers in developing countries, livestock production is only approximately $20 \%$ of agricultural output. This situation has persisted, despite the rapidly rising demand for milk and meat in countries where there has historically been very limited access to these animal-source foods (ASF) rich in protein [1]. With global meat and milk production projected to increase another 19 and 33\% by 2030, respectively [2], improved adoption of existing and emerging "best practice" technologies is required. This includes improvement of feeding resources, adoption of preventive health management interventions and biosecurity, husbandry initiatives with optimal manure management, plus enhanced marketing strategies. As large ruminant production has been associated with high outputs of greenhouse gas emissions (GHGe), it has been estimated 
that these improved production efficiencies could potentially assist the global livestock sector to reduce GHGs by as much as $30 \%$ [1].

Buffalo (Bubalus bubalis) is a species considered an efficient converter of poor-quality forages into high quality milk and meat, with a population currently exceeding 205 million animals [3]. Since the domestication of water buffalo approximately 5000 years ago, they have become economically important animals, providing over $5 \%$ of the world's milk supply, with their milk exceedingly rich, containing less water and more fat, lactose, and protein than milk from cattle [4]. Buffalo milk is used to make butter, butter oil (ghee), high quality cheeses, and various other products. Further, their meat is palatable and difficult to differentiate from beef, their hides are important for leather products, their faeces a source of fertiliser, and they still have a major role in supplying draught power, providing 20 to $30 \%$ of power for cultivation and transportation in Southeast Asia [4]. Buffalo are almost ubiquitous, with a higher prevalence in Asian and Mediterranean countries. The two main sub-species include river buffalo, found predominantly in Mediterranean countries, and swamp buffalo, found mainly on the Asia continent. The majority (96\%) of the total world buffalo population is distributed in Asia, particularly India, China, Pakistan, Thailand, The Philippines, Indonesia, Burma, Sri Lanka, and Egypt [5], with a feral population increasingly prevalent in northern Australia. Milk producing buffaloes are mostly found in Pakistan, India, and Egypt. In most other countries, swamp subspecies predominate, historically used for draught and increasingly for meat, although recently, several countries have introduced milk-producing animals to increase lactation yields [3-5]. In Southeast Asia, swamp buffalo are mostly fed on low-quality roughages and crop residues with poor nutritive value, resulting inevitably in reduced productive and reproductive performances $[6,7]$. A distinctive differential production system has been noted between river and swamp buffaloes due to the significant production capacity of the two sub-species, although water buffalo are generally considered to be undervalued and a species with possibly the greatest potential for production improvements [5]. With expansion of the economies of China and most countries in Southeast Asia increasing the demand for consumption of red meat, plus widespread adoption of farm mechanisation, the role of swamp buffalo has largely changed from a source of draught power to meat production [6,7].

The Lao People's Democratic Republic (Lao PDR or Laos henceforth) is a landlocked country where $77 \%$ of all households still rely on mainly subsistence agriculture for their livelihoods, and over a third of agricultural households maintain cattle and/or buffalo, typically in herds of five to 10 heads in smallholder mixed-farming systems [6,7]. These large ruminants are mostly grazed, used for manure production to support rice and crop cultivation, plus function as "banks" that can be sold for beef or as store animals when household finances require cash. Until very recently, milking of buffalo in Laos had not occurred. Buffalo are a very important livestock species in Laos, with smallholder farmers owning the majority of an estimated 774,200 buffalo located with an estimated 226,400 farming households, and $78 \%$ of these farms having a herd size of four or less [6]. The total meat consumption in Laos and China was approximately 21 and $58 \mathrm{~kg}$ per capita in 2009, with an annual growth rate forecast of 4.5 and 3.1\% [6]. Increasing demand for buffalo meat and more recently milk in both domestic and neighbouring markets offers important opportunities for smallholders to gain more income from their buffalo, enhancing food security and reducing rural poverty. However, improving buffalo production requires numerous constraints to be addressed, including nutritional deficits; low reproductive performance and presence of reproductive pathogens; high slaughter rates of pregnant cows; undeveloped trade and marketing systems; limited veterinary and extension service capacity, health issues, including parasitism (particularly Toxocara vitulorum), endemic diseases (particularly haemorrhagic septicaemia (HS) and in some locations blackleg control), and transboundary diseases, especially foot and mouth disease (FMD) due to poor biosecurity controls, and potentially, climate change and policy impacts [6-8].

Native water buffalo in Laos have a mature body weight of 300-350 kg [6]. In the wet season from June to November, buffalo are grazed on native tropical grasses occurring 
on any available owned, communal, vacant, or forested land not in cultivation for rice and other crops. During the dry season when rice cultivation ceases, large ruminants are typically tethered on paddy lands and offered a diet of emerging but lowly abundant native grasses and rice straw collected from post-rice-harvest fields. As rice straw has low metabolisable energy and crude protein estimated at 4-6.5 MJ $/ \mathrm{kg}$ dry matter and 2-6\%, respectively [9], depletion of weight in the dry season is common, especially for lactating animals [6]. With government-led rezoning of forests for reforestation [10] and increased dry season irrigation for non-rice cropping, decreasing land resources are available for livestock grazing, further constraining nutrient availability for large ruminants and impacting negatively on large ruminant body weights, measured as declines in average daily gains (ADG). Longitudinal data on buffalo production from Laos have identified that in January 2010 in the early dry season, ADGs were -67 to $2 \mathrm{~g} /$ day, whereas in March 2009 in the late dry season, ADGs were -21 to $23 \mathrm{~g} /$ day [6]. These dry season ADGs were considerably lower than both the early and late wet season ADGs of 223 to $282 \mathrm{~g} /$ day and ADGs of 123 to $247 \mathrm{~g} /$ day in buffalo, respectively [6]. Decreased animal condition in the dry season has implications for on-farm production efficiency and profitability, with post-partum anoestrus contributing to extended inter-calving intervals, estimated at 19-26 months in buffalo $[6,8,11]$.

Evidence has been accumulating on the efficacy of molasses block technology in successfully enhancing large ruminant productivity, with molasses nutrient blocks (MNB) conveniently enabling supplementation of the generally inefficient large ruminant production system in a number of countries [12], including most recently Laos [13-15]. This has been demonstrated in beef animals, with improved nutrition and parasite control increasing growth rates, particularly in younger animals, presumably through improving lactation yields, with and without the inclusion of $8 \%$ urea (UMNB8) in the molasses nutrient block [13-15]. However, to measure the improved lactation that can accrue from supplementation with access to high-quality molasses blocks containing 10\% urea, a trial was conducted to examine the efficacy of ad libitum supplementation of the diet of lactating Asiatic swamp buffalo used for milk production in a recently constructed buffalo dairy enterprise in Laos aimed at the speciality manufacture of buffalo mozzarella cheese for the local tourist industry. This research trial examined the lactation yields and body condition scores (BCS) of buffalo cows supplemented with "cow-calf" molasses nutrient blocks containing $10 \%$ urea (UMNB10), to be compared with yields and BCS from lactating buffalo without supplementation. Further, the economic potential of this intervention was evaluated by partial budget analysis. Evaluation of this technology may provide commercial opportunities for provision of molasses blocks into smallholder production systems, potentially creating both positive change management for poor rural families and reduction in GHGe from more efficient buffalo productivity in developing countries.

\section{Materials and Methods}

\subsection{Housing and Animals}

The trial was conducted in the Luang Prabang Buffalo Dairy in Luang Prabang Province, Laos, a highly biosecure facility with a separate quarantine facility, capable of housing up to 100 animals on concreted floors, enclosed by steel railings and covered with iron roofing but with open walls for flow-through ventilation. The trial utilised $(n=26)$ genetically unimproved buffalo cows "leased" from smallholder farming families in local villages, introduced prior to parturition and retained with their calves for the duration of their lactation. These were animals formerly providing draught for cultivation and transport but are now mostly retained for cash storage, meat trading, and household consumption. The trial involved three groups of up to 9 buffalo in each group, housed in separated pens, with a control group (D1) and two treatment groups (C1 and C2). There were no differences between the $C$ groups, although several animals were removed late in the trial (especially from group C2) due to a transient decrease in local demand for buffalo milk products (Table 1). On this farm, buffalo were routinely milked once daily in the 
morning, providing data on DMP, with their calves provided with access to their mothers following milking, until early evenings when they were separated overnight. The animals were regularly vaccinated against haemorrhagic septicaemia (HS) and foot-and-mouth disease (FMD) and the facility remained FMD-free despite a major outbreak occurring in adjacent villages supplying animals to the dairy [16].

Table 1. Number of observations of milk production for each treatment group.

\begin{tabular}{cccc}
\hline Day/Month & D1 Control & C1 Treatment & C2 Treatment \\
\hline 12 February & 8 & 6 & 9 \\
19 February & 9 & 8 & 9 \\
26 February & 8 & 8 & 9 \\
2 March & 8 & 8 & 9 \\
4 March & 8 & 8 & 8 \\
11 March & 8 & 8 & 5 \\
18 March & 8 & 7 & 5 \\
25 March & 7 & 6 & 3 \\
\hline Total & 64 & 59 & 57 \\
\hline
\end{tabular}

\subsection{Trial Design and Supplementation}

At trial commencement, the groups were matched as closely as possible to minimise initial differences between groups, including age, BCS, genotype (no Murrah cross animals included), and volumes of forage offered. The average BCS was 2.9/5 and all animals had well-established (mid) lactations. They were fed a fresh forage-based diet, provided three times daily, consisting of a mix of $30 \mathrm{~kg}$ of Napier grass (Pennisetum purpureum), $750 \mathrm{~g}$ corn and $1.45 \mathrm{~kg}$ of rice bran, plus ad libitum access to fresh Mulatto grass (Brachyaria sp.). Two of the groups ( $\mathrm{C} 1$ and $\mathrm{C} 2$ ) were also provided with ad libitum access to "cow-calf" nutrient molasses blocks containing 10\% urea and additional phosphorus, supplied from Australia (Four Seasons Company Pty Ltd., Brisbane). The block supplements were designed to meet the following challenges: (1) resist meltdown from tropical heat and be resistant to rain; (2) deliver components in a safe preparation that enables sufficient intake of nutrients; (3) contain optimal available phosphorus, sulphur, nitrogen, and other minerals; (4) contain GHGe-reducing agents. No additional supplementation was provided to the third group (D1; control), and no disease issues of relevance were observed (e.g., mastitis) during the trial. For BCS, each buffalo was scored up to three times, in January, February-March and April (Table 2), and milk production $(\mathrm{kg})$ was recorded up to eight times between 12 February and 25 March (Table 1).

Table 2. Number of observations of body condition score for each treatment group.

\begin{tabular}{cccc}
\hline Month & D1 Control & C1 Treatment & C2 Treatment \\
\hline January & 9 & 8 & 9 \\
February-March & 9 & 8 & 6 \\
April & 9 & 7 & 6 \\
\hline
\end{tabular}

\subsection{Statistical Methods}

Data on individual-level buffalo milk production and body condition scores (BCS) were entered into spreadsheets in Excel. The data from nine buffalo in Group D1 (Control), eight in Group C1 (Treatment), and nine in Group C2 (Treatment) were available for analysis. Since there were repeated measures for both milk production and BCS, linear mixed models were used to analyse both traits. For milk production, fixed effects of the model were group (three-level factor), day (eight-level factor), as well as a group $\times$ day interaction to assess different time courses for each treatment group, and a random effect for each buffalo was included to account for the repeated measures. In addition, day of birth (DOB) and days in milk (calculated by date difference from DOB) were assessed 
separately as additional fixed effect covariates, but both were found to be not significant and were not included in the model.

For BCS, the fixed effects were group and month, as well as the group $\times$ month interaction. Again, a random effect for each buffalo was included in the model, and DOB was examined but not included as found to be non-significant.

For both traits, the analyses were re-run after collapsing the two treatment groups into a single group, i.e., an overall treatment vs. control comparison. The same statistical models were used for these analyses and for the original three-level treatment group analyses. All analysis was conducted using the R statistical software. Mixed models were fitted using the "lmer" function in the "lme4" package [17], and statistical significance testing conducted using likelihood ratio tests (chi-square approximation). Model-based means were extracted and compared using the "emmeans" [18] and "multcomp" packages [19].

\subsection{Partial Budget Analysis}

A partial budgets analysis was conducted to provide a simple economic comparison of the addition of molasses nutrient supplementation to the diet of the lactating buffalo in Groups C1 and 2 (supplementation plan) compared to un-supplemented animals in D1 (base plan). This approach was considered appropriate, as the outcome did not involve a specific time pattern or a high degree of uncertainty [20]. The partial budget examined the following four components of the comparison of supplementation plan to the base plan: (1) any additional returns that accrued from the provision of supplementation; (2) any reduced costs that may have occurred from use of the supplementation; (3) listing of any items or costs avoided following adoption of supplementation; (4) identification of any returns forgone from adoption of the supplementation plan. The partial budget model was constructed in Excel to identify the economic impact (benefit or cost) that occurs when the enterprise uses the molasses blocks over a 30-day period. Adoption of the supplementation plan would require that the sum of (1) and (2) exceeds that of (3) and (4).

\subsection{Ethics Statement}

The methodologies used in this study complied with the Universities Australia Australian Code for the Responsible Conduct of Research. The study was conducted in association with projects approved by the Animal and Human Ethics approval process of the University of Sydney Ethics Committees (project no. 2015/765 and 2014/783, respectively).

\section{Results}

\subsection{Milk Production}

The number of observations of milk production data across the study period, for each treatment group as displayed (Table 1), indicates that counts were constant apart from the C2 treatment group from 11 March onwards, due to the necessity of reducing the milk produced due to temporarily diminished local demand for cheese. There was a significant group $\times$ day interaction $(p=0.023)$, indicating that the time courses of milk production across the three groups were significantly different (note that because of the significant interaction, the main effects of group and day cannot be meaningfully tested). Model-based means are displayed (Figure 1).

The means, standard errors, and pairwise comparisons within each day are also displayed (Table 3). Milk production was constant for D1 (control) animals, but somewhat higher for $\mathrm{C} 1$ and $\mathrm{C} 2$ (treatment) animals 21 days into the study. C1 (treatment) means were significantly greater than D1 (control) on 19 February (day 7 of trial) and on 25 March (day 42 of trial). C2 (treatment) means never reached threshold significance in relation to controls.

After collapsing the two treatment groups together, there was a significant group $\times$ day interaction $(p=0.023)$, the same significance level as with the separate treatment groups. Model-based means for this analysis are shown (Figure 2 and Table 4). Milk production in the 
combined C1 and C2 (treatment) group was significantly greater than that of D1 (control) on days 7 and 42, as in the analysis for the C1 (treatment) group above.

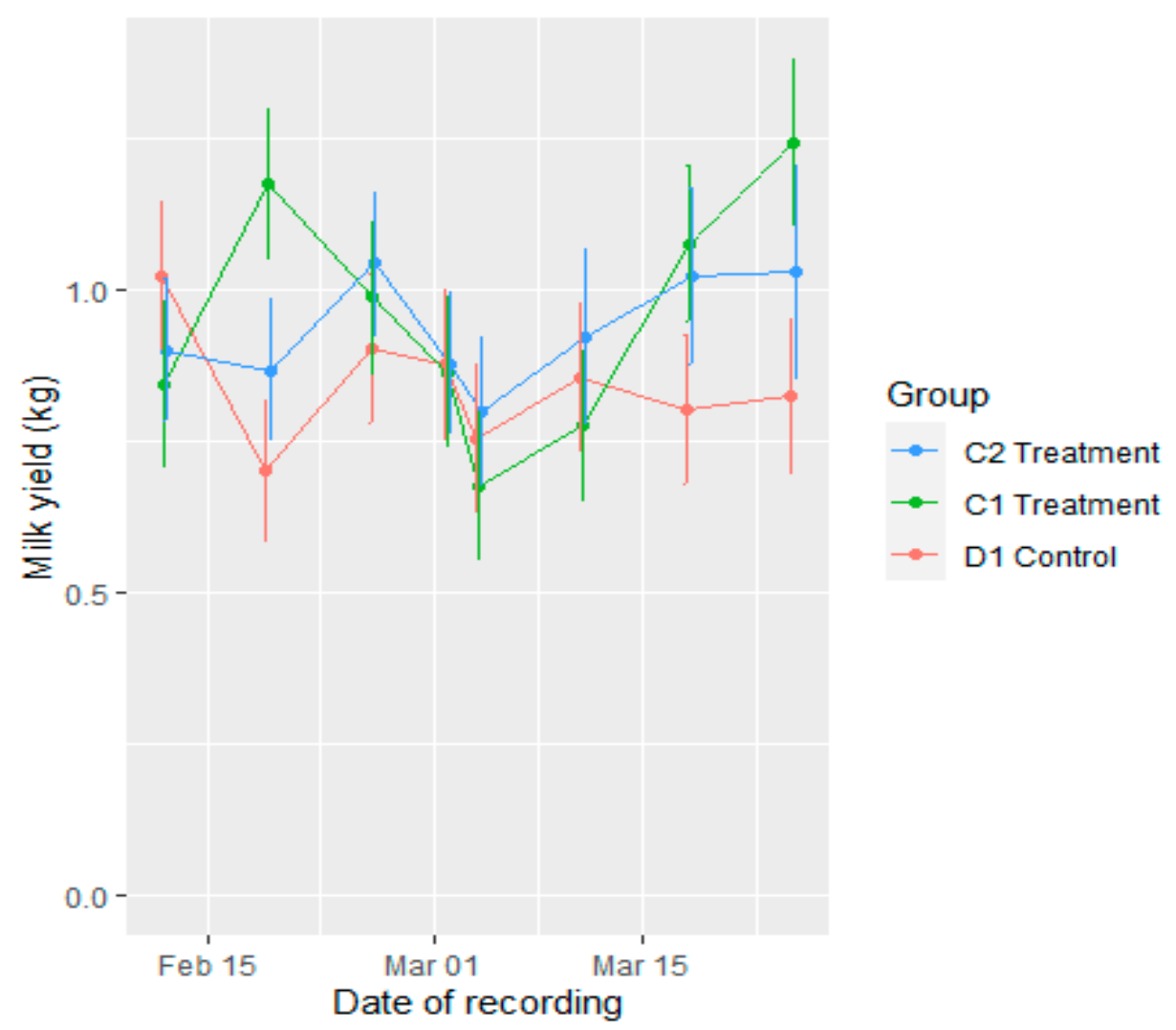

Figure 1. Model-based mean milk production $(\mathrm{kg})$ across the eight sample times for the three treatment groups. Error bars are standard error of the means.

Table 3. Model-based mean milk production $(\mathrm{kg}) \pm$ standard error for buffalo in each treatment group across the study period.

\begin{tabular}{cccc}
\hline Day/Month & D1 Control & C1 Treatment & C2 Treatment \\
\hline 12 February & $1.02 \pm 0.12^{\mathrm{A}}$ & $0.84 \pm 0.14^{\mathrm{A}}$ & $0.90 \pm 0.12^{\mathrm{A}}$ \\
19 February & $0.70 \pm 0.12^{\mathrm{A}}$ & $1.18 \pm 0.13^{\mathrm{B}}$ & $0.87^{\mathrm{A}} \pm 0.13^{\mathrm{A}, \mathrm{B}}$ \\
26 February & $0.90 \pm 0.12^{\mathrm{A}}$ & $0.99 \pm 0.13^{\mathrm{A}}$ & $1.04 \pm 0.12^{\mathrm{A}}$ \\
2 March & $0.88 \pm 0.12^{\mathrm{A}}$ & $0.86 \pm 0.13^{\mathrm{A}}$ & $0.88^{\mathrm{A}} \pm .12^{\mathrm{A}}$ \\
4 March & $0.75 \pm 0.12^{\mathrm{A}}$ & $0.68 \pm 0.13^{\mathrm{A}}$ & $0.80 \pm 0.12^{\mathrm{A}}$ \\
11 March & $0.85 \pm 0.12^{\mathrm{A}}$ & $0.78 \pm 0.13^{\mathrm{A}}$ & $0.92^{\mathrm{A}} \pm 0.15^{\mathrm{A}}$ \\
18 March & $0.80 \pm 0.12^{\mathrm{A}}$ & $1.08 \pm 0.13^{\mathrm{A}}$ & $1.02^{\mathrm{A}} \pm 0.15^{\mathrm{A}}$ \\
25 March & $0.82 \pm 0.13^{\mathrm{A}}$ & $1.24 \pm 0.14^{\mathrm{B}}$ & $1.03^{\mathrm{A}} \pm 0.18^{\mathrm{B}}$ \\
\hline
\end{tabular}

$\overline{\mathrm{A}, \mathrm{B}}$ : Means sharing the same superscript on a month are not significantly different $(p>0.05)$.

Table 4. Model-based mean milk production $(\mathrm{kg}) \pm$ standard error for buffalo in the control and combined treatment group across the study period.

\begin{tabular}{ccc}
\hline Day/Month & Control & Treatment \\
\hline 12 February & $1.02 \pm 0.12^{\mathrm{A}}$ & $0.88 \pm 0.09^{\mathrm{A}}$ \\
19 February & $0.70 \pm 0.12^{\mathrm{A}}$ & $1.01 \pm 0.08^{\mathrm{B}}$ \\
26 February & $0.90 \pm 0.12^{\mathrm{A}}$ & $1.02 \pm 0.08^{\mathrm{A}}$ \\
2 March & $0.88 \pm 0.12^{\mathrm{A}}$ & $0.87 \pm 0.08^{\mathrm{A}}$ \\
4 March & $0.75 \pm 0.12^{\mathrm{A}}$ & $0.74 \pm 0.09^{\mathrm{A}}$ \\
11 March & $0.85 \pm 0.12^{\mathrm{A}}$ & $0.83 \pm 0.09^{\mathrm{A}}$ \\
18 March & $0.80 \pm 0.12^{\mathrm{A}}$ & $1.05 \pm 0.10^{\mathrm{A}}$ \\
25 March & $0.82 \pm 0.13^{\mathrm{A}}$ & $1.17 \pm 0.11^{\mathrm{B}}$ \\
\hline
\end{tabular}

$\overline{\mathrm{A}, \mathrm{B}}$ : Means sharing the same superscript on a day are not significantly different $(p>0.05)$. 


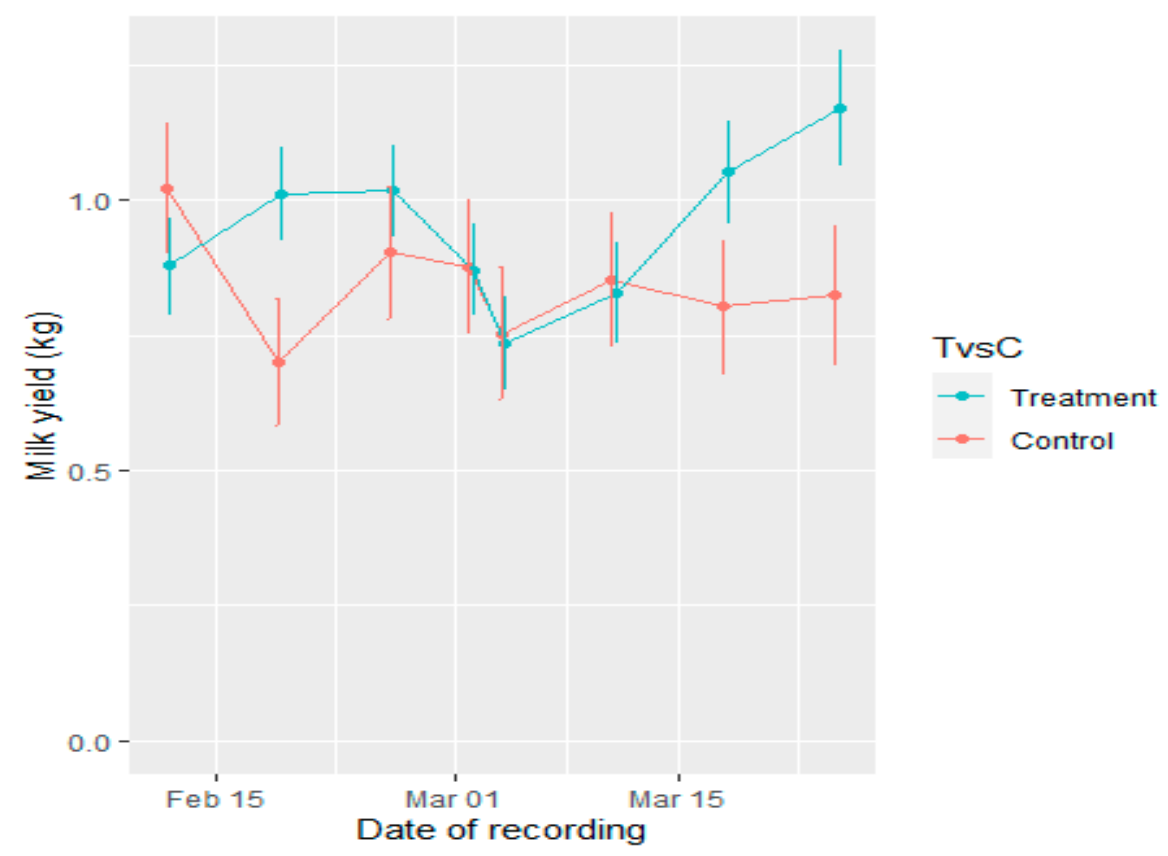

Figure 2. Model-based mean milk production $(\mathrm{kg})$ across the eight sample times for the control and combined treatment groups. Error bars are standard error of the means.

\subsection{Body Condition Score}

The number of observations of BCS data across the study period, for each treatment group as displayed (Table 2), indicates that counts were constant apart from the C2 in February-March and April. There was a significant group $\times$ month interaction $(p=0.015)$, indicating different time trends for BCS across the three treatment groups. Like milk production, BCS for the control groups remained constant. BCS for $\mathrm{C} 1$ treatment and $\mathrm{C} 2$ treatment increased over the study, but only $\mathrm{C} 2$ treatment was significantly greater that D1 control in April (Figure 3, Table 5).

Table 5. Model-based mean body condition score \pm standard error for buffalo in each treatment group across the study period.

\begin{tabular}{cccc}
\hline Month & D1 Control & C1 Treatment & C2 Treatment \\
\hline January & $2.90 \pm 0.044^{\mathrm{A}}$ & $2.90 \pm 0.047^{\mathrm{A}}$ & $2.86 \pm 0.044^{\mathrm{A}}$ \\
February-March & $2.91 \pm 0.044^{\mathrm{A}}$ & $3.02 \pm 0.047^{\mathrm{A}}$ & $2.92 \pm 0.050^{\mathrm{A}}$ \\
April & $2.87 \pm 0.044^{\mathrm{A}}$ & $3.04 \pm 0.049^{\mathrm{B}}$ & $2.90 \pm 0.050^{\mathrm{A}, \mathrm{B}}$ \\
\hline A,B: Means sharing the same superscript on a month are
\end{tabular}

$\overline{\mathrm{A}, \mathrm{B}}$ : Means sharing the same superscript on a month are not significantly different $(p>0.05)$.

When the two treatment groups were collapsed into a single group, there was a somewhat more significant group $\times$ month interaction $(p=0.009)$. However, while mean BCS was higher in the combined treatment group compared to the control in February-March and April, it failed to reach statistical significance (all $p>0.05$ ) (Table 6, Figure 4).

Table 6. Model-based mean milk production $(\mathrm{kg}) \pm$ standard error for buffalo in the control and combined treatments group across the study period.

\begin{tabular}{ccc}
\hline Month & Control & Treatment \\
\hline January & $2.90 \pm 0.047^{\mathrm{A}}$ & $2.88 \pm 0.034^{\mathrm{A}}$ \\
February-March & $2.91 \pm 0.047^{\mathrm{A}}$ & $2.98 \pm 0.036^{\mathrm{A}}$ \\
April & $2.87 \pm 0.047^{\mathrm{A}}$ & $2.98 \pm 0.036^{\mathrm{A}}$ \\
\hline
\end{tabular}

$\mathrm{A}$ : Means sharing the same superscript on a month are not significantly different $(p>0.05)$. 


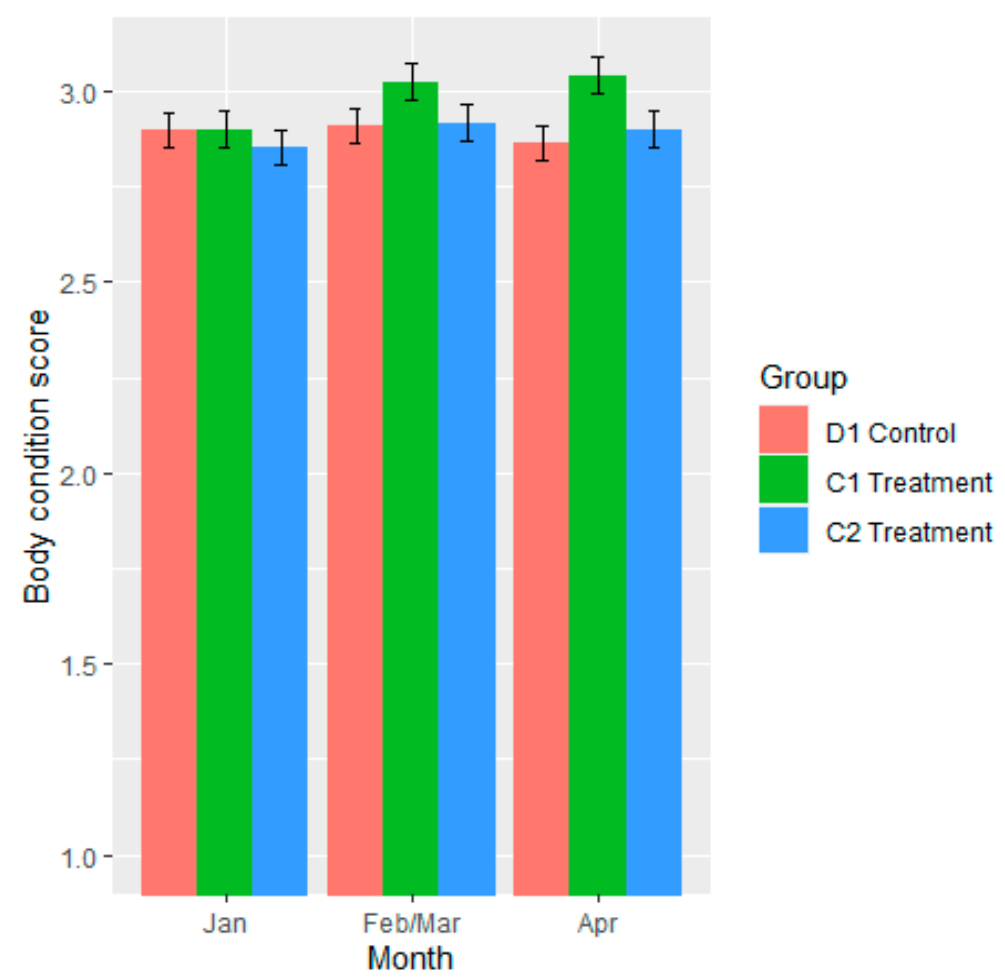

Figure 3. Model-based body condition score across the three sampling periods for the three treatment groups. Error bars are standard error of the means.

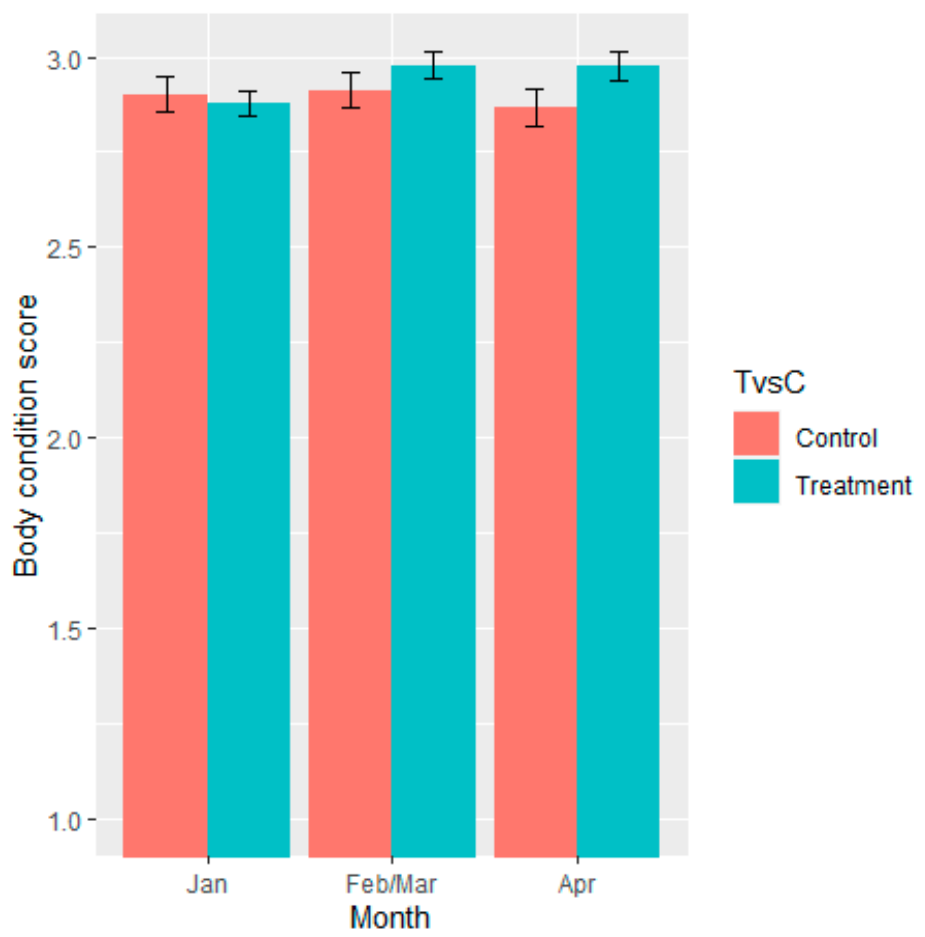

Figure 4. Model-based body condition score across the three sampling periods for the control and combined treatment groups. Error bars are standard error of the means.

\subsection{Partial Budget Analysis}

\subsubsection{Additional returns}

The additional returns are primarily derived from the increased milk production in each of the treatment groups $\mathrm{C} 1$ and $\mathrm{C} 2$. Nine buffalo were assigned to each of treatment 
groups, and each group was provided with three molasses blocks for the duration of the trial. The modelling of the daily milk production data indicated that on average, lactating buffalo in group $\mathrm{C} 1$ produced an extra $240 \mathrm{~mL}$ of milk per day, and those in group C2 an extra $180 \mathrm{~mL}$ per day. A 30-day period was set for the model to calculate the total extra milk for each group. It is estimated that for each $\mathrm{kg}$ of cheese produced, $5 \mathrm{~L}$ of raw milk is required. Therefore, the model could calculate the estimated additional cheese produced from the two treatment groups receiving the molasses lick blocks. The buffalo cheese enterprise has an average sale price for cheese of USD 35 per kilo. Thus, the total additional returns were calculated at USD 453.60 for group C1 and USD 340.20 for group C2 (Table 7).

Table 7. Partial budget analysis for inclusion of molasses blocks in treatment group C1 and C2.

\begin{tabular}{|c|c|c|c|c|c|}
\hline & \multirow{2}{*}{ Partial Budget } & \multicolumn{2}{|c|}{ Group C1 } & \multicolumn{2}{|c|}{ Group C2 } \\
\hline & & Input Values & Total (USD) & Input Values & Total (USD) \\
\hline & Additional returns & & & & \\
\hline a & No. buffalo provided blocks (head) & 9.00 & & 9.00 & \\
\hline $\mathrm{b}$ & Increased milk yield (kg/day/buffalo) & 0.240 & & 0.180 & \\
\hline c & Days of lactation & 30 & & 30 & \\
\hline $\mathrm{d}$ & Total increase milk per 30 day period & 65 & & 49 & \\
\hline $\mathrm{e}$ & No. litres of milk to make $1 \mathrm{~kg}$ cheese & 5 & & 5 & \\
\hline $\mathrm{f}$ & Additional cheese $\mathrm{kg}$ produced & 12.96 & & 9.72 & \\
\hline \multirow[t]{5}{*}{$\mathrm{g}$} & Value per kg of cheese (USD) & 35.00 & & 35.00 & \\
\hline & Total additional returns & & 453.60 & & 340.20 \\
\hline & Total reduced costs & & 0.00 & & 0.00 \\
\hline & Total returns foregone & & 0.00 & & 0.00 \\
\hline & Extra costs & & & & \\
\hline j & Cost to make total extra cheese & 32.40 & & 24.30 & \\
\hline $\mathrm{k}$ & Price of molasses block (USD) & 15.00 & & 15.00 & \\
\hline 1 & Number of molasses blocks & 3.00 & & 3.00 & \\
\hline $\mathrm{m}$ & Days molasses blocks deployed & 1.00 & & 1.00 & \\
\hline \multirow[t]{3}{*}{$\mathrm{n}$} & Labour cost (USD*person hours) & 0.21 & & 0.21 & \\
\hline & Total extra costs & & 45.21 & & 45.21 \\
\hline & Net benefit (USD) & & 408.40 & & 295.00 \\
\hline
\end{tabular}

\subsubsection{Reduced Costs}

As molasses blocks provide nutritional supplementation, their use does not offset feed requirements that differed from the control group. For the purpose of this model, no reduced costs were included. However, use of the blocks may have further benefits relating to animal health, lifetime productivity, that may lower lifetime health treatment costs. Further, greenhouse gas emissions (GHG) from inefficient ruminant systems can be reduced through improved lifetime productivity, and this may lead to further reduced costs if GHG output is recognised as a farm cost in Laos.

\subsubsection{Returns Forgone}

For the purposes of this analysis, the returns foregone were considered to be zero, as the enterprise did not report any income losses associated with the use of these molasses blocks.

\subsubsection{Extra Costs}

The extra cost of the alternative plan is the purchase and administration of the molasses block and extra costs associated with producing extra cheese in the enterprise. The farmgate price for each molasses block was estimated by the molasses block manufacturer at USD 15 per block. Each group received three blocks for the duration of the trial. A one-time administration of the blocks into the buffalo yards required minimal time (estimated at $15 \mathrm{~min}$ ); therefore, although increased labour was added to the model, this was minimal. Total extra costs were recorded at USD 45.21 for both treatment groups. 


\section{Discussion}

This research trial aimed to further examine the recent research findings in Laos conducted with beef animals, confirming that significant improvements in ADG could accrue from supplementation with high-quality MNB and UMNB8 [13-15], with young calves having the highest ADG (251-265 g/day) presumably due to their access to increased milk from their dams [15]. The preliminary findings in this trial in a buffalo dairy, following supplementing of the forage-based diet of lactating buffalo with ad libitum access to "cow-calf" UMNB10, are indicative of considerable increases in daily milk production, without a loss in BCS. The trial suggests an advantage of up to a $31 \%$ increase in daily milk production, albeit from a very low base milk yield level, as a result of block supplementation for several months. This provides additional evidence of the efficacy of quality molasses block technology in successfully enhancing productivity through supplementation of the generally inefficient large ruminant smallholder production system, as demonstrated previously in dairy buffalo in other countries [12] and recently in beef animals in Laos [13-15].

Previous trials with UMNB-supplemented buffaloes in South Asia [12] also showed increased milk yield and higher milk fat values than did their un-supplemented counterparts, calculated as an average increase of $8 \%$ milk yield and 0.5 percentage unit milk fat [21]. It is considered likely that the higher average percentage increase in milk yield in supplemented buffaloes in Laos may reflect several factors, including that these animals were offered higher quality blocks manufactured with superior technology to deliver additional nutritional components. Further, as swamp buffaloes in Laos are genetically unselected for dairy production, their markedly lower yields have more potential to be improved in response to nutritional supplementation. Finally, it is possible that the addition of urea to provide non-protein nitrogen for hydrolysis in the rumen to ammonia [15] appears also to have enabled the rumen micro-organisms of these unimproved buffalo to enhance their degradation of the roughages in the diet, leading to superior amino acid and protein synthesis availability during digestion.

Partial budget analysis provides a simple economic assessment to evaluate the net benefit or cost of an intervention into a farm system. This analysis indicated that a strong incentive exists for the enterprise to include molasses blocks, as three molasses blocks per nine lactating buffalo provided a net benefit of USD 408.40 and USD 295.00 for treatment groups $\mathrm{C} 1$ and $\mathrm{C} 2$, respectively, over the control group. This result reflects that this buffalo mozzarella cheese enterprise involves a vertically integrated specialty food production system that enables significant value add-on to the milk to be captured at the farm enterprise level. This product is designed for the tourist market. However, the Lao buffalo dairy program also aims to educate farmers to milk their lactating buffalo cows when they are returned to the villages, using the milk for household consumption or for local sale. Further data are required to model molasses block economic impacts on potential smallholder dairy producers and their families in Southeast Asia where milk is sold at the farm gate and/or consumed locally. This initiative is particularly important for rural children in developing countries where stunting in children is common. Although Laos has made significant gains in reduction in childhood stunting, from $48 \%$ in previous reports [22], down to $33 \%$ in 2017 [23], surveys suggest that 11 out of 18 provinces still have critical levels of stunting above the WHO recommended threshold of 30\%. As wide disparity exists in the prevalence of stunting among people living in different geographical areas, by wealth quintile, and ethnicity, and stunted children have reduced capacity to learn in school, grow to their fullest potential, and achieve maximum economic benefits in adult life, nutritional programs that can include ASF and, in particular, dairy products have important health implications.

Financial motivations to improve buffalo production efficiency have been increasing, particularly in Southeast Asia, where buffalo live-weight prices (USD/tonne) increased by more than $800 \%$ from 2000 to 2012 in response to growing regional beef consumption [6]. As this trend has continued in Southeast Asia, opportunities have arisen for smallholder farmers to significantly improve their livelihoods, mainly through supply of large ru- 
minants for regional beef markets [6]. There is also enormous potential for improved rural smallholder livelihoods from milk production from buffalo, particularly in countries such as Laos where there has been limited supply and use of milk, despite a clear need for increased ASF to improve childhood nutrition. However, for smallholders to exploit these opportunities, there are many challenges that need to be addressed $[6,8,24,25]$. Most livestock farmers in developing countries have low animal husbandry skills, minimal nutritional, biosecurity, animal disease and reproductive management knowledge, poor access to markets, and high rates of illiteracy. Further, extension and veterinary services plus the supply of products for livestock health and production from rural stores in developing countries are usually limited, increasing the difficulties for smallholders to use nutritional, health, reproductive, and other interventions to adopt and manage the changes required to improve their productivity $[6,25]$.

With the current rapid rate of economic development expected to continue in Laos and the Greater Mekong Subregion, expansion of the domestic and regional markets for food requires a more biosecure and sustainable supply of safe meat and milk. Improving livestock health, productivity, processing, and marketing, particularly of buffalo, is critical to ensuring poor smallholder communities can participate in and access these growing markets, providing improved rural livelihoods, poverty reduction, and increased food security. This also requires increasing the availability of high-quality nutritional supplementation plus health prevention and therapeutic options for smallholder farmers with buffalo [13-16]. Facilitating the transition of smallholder buffalo keepers to more market-oriented producers requires that livestock development policies in Laos promote the adoption of a multiple intervention approach to modernising large ruminant livestock production. This needs to address the many constraints identified, with improved animal feeding and husbandry technologies, enhanced large ruminant health and disease risk management including farmer biosecurity knowledge and practices, the introduction of modern reproductive practices, plus measures that improve animal and product marketing linkages. All of these initiatives can assist smallholder buffalo farmers to improve their livestock productivity and gain better market access, leading to enhanced rural family livelihoods. This strategy requires a "change management" learning process that requires identification of motivational drivers of change adoption [24]. It also requires ongoing support and close collaboration with research and development programs to improve extension capacity, animal movement control, disease surveillance, public awareness, vaccination programs, feed resources, and reproductive management $[6,25]$.

Of particular interest in managing positive livestock productivity change is identifying the project "entry point" that can most motivate farmers to invest time and resources into improving the quality of their animals. Molasses blocks present a potentially important project entry point intervention for livestock development programs. The use of MNBs appears to motivate farmers to readily improve their cattle and buffalo production efficiency, as they rapidly see visible evidence of improvement in the quality of their animals [13-15]. In addition, MNBs provide a convenient intervention that more rapidly addresses the extended lag period required when establishing forage plantations for animal feeding [6,25]. This is particularly important in dry seasons, when nutrition is often severely limited, and in developing countries, where lack of cattle handling equipment means administration of medications is difficult [13-15]. The findings from this trial add to the growing evidence that molasses blocks are a convenient change management entry point for motivating farmers to adopt a productivity approach. This assists the current planning by the company providing the blocks, to develop a molasses nutrient block manufacturing plant in the vicinity of Luang Prabang in northern Laos. It also encourages the continuation of collaborative arrangements aimed at developing a nutritional block supplementation strategy to significantly improve large ruminant production efficiency in other developing countries.

With GHGe along livestock supply chains estimated at 7.1 gigatonnes $\mathrm{CO}$-eq per annum, representing $14.5 \%$ of all human-induced emissions, the livestock sector is an important contributor to climate change [1-3]. The animal commodities contributing most 
of the sector's GHGe are from cattle, contributing about 4.6 gigatonnes $\mathrm{CO} 2$-eq or $65 \%$ of sector emissions from beef and cattle milk production. Beef contributes 2.9 gigatonnes $\mathrm{CO} 2$-eq, or $41 \%$, and cattle milk 1.4 gigatonnes $\mathrm{CO} 2$-eq, or $20 \%$ of total sector emissions, respectively. Buffalo milk and meat contribute 0.6 gigatonnes $\mathrm{CO} 2$-eq or $8 \%$, with small ruminant milk and meat contributing $6 \%$. Beef produced by dairy cattle has generally lower emission intensity than beef produced by specialised beef cattle, as GHGe from reproductive animals are allocated to milk and meat in the case of the dairy herd, and to meat only in the case of the beef herd. Importantly, beef and milk production have higher emission intensities in low productivity systems. This is due to low feed digestibility, less efficient herd management practices and low reproduction performance. Findings that identify significant increases in large ruminant livestock productivity offer potentially important opportunities for mitigation of GHGe from production of livestock products. As improved productivity potentially enables the global livestock sector to reduce GHGe by as much as 30 percent [2], the use of MNBs that have the potential to improve milk yields by up to $31 \%$ is an important finding. This research suggests that high-quality MNBs may assist in creating a more sustainable global future for mankind through a more appropriate food production system that addresses climate change risks.

A multi-intervention livestock development strategy involving a combination of nutritional and health interventions has been proposed for scale-out to assist smallholder large ruminant livestock farming efficiency in developing countries [15]. The strategy includes a combination of established forage plantations and improved feeding, with multiple health interventions involving efficacious vaccination, biosecurity, and parasite management programs [13-15]. Recent findings have indicated that this strategy can be precipitated by use of high-quality molasses blocks to improve rumen function [15] and are supported by the findings in this paper of up to $31 \%$ improvement in milk production in unimproved swamp buffalo from provision of UMMB10. Scale-out of this strategy is now recommended, as it offers important socioeconomic benefits for improved community resilience in poor rural communities, in addition to potentially enabling the global livestock sector to reduce GHGe by as much as 30\% [2] and diminishing the risks of the impending climate change catastrophe.

Author Contributions: P.W. generated the concept, designed the methodology for this trial, and drafted and finalised the manuscript. S.M. conducted the trial, with local authorisation and receipt of and block storage by S.K., with statistical support provided by P.T. and financial analysis by J.Y., who both contributed to the completion of manuscript with R.B. All authors have read and agreed to the published version of the manuscript.

Funding: Funding for research trials in Laos on improving smallholder farmer livelihoods through large ruminant health and production interventions including supplementation strategies was initially provided through the Australian Centre for International Agriculture Research (ACIAR, http:/ / aciar.gov.au/), with ongoing support provided by the Australian Department of Foreign Affairs and Trade Business Partnership Platform project "Enhancing Livelihoods of Smallholder Famers in Laos" (https:/ / thebpp.com.au/partnership/enhancing-livelihoods-of-smallholder-farmers-in-laos/).

Institutional Review Board Statement: This study complied with the Universities Australia Australian Code for the Responsible Conduct of Research and was conducted in association with projects approved by the Animal and Human Ethics approval process of the University of Sydney Ethics Committees (project no. 2015/765 and 2014/783, respectively).

Informed Consent Statement: Not applicable.

Data Availability Statement: The data derived in this study is available on request from the authors.

Acknowledgments: The authors thank the staff at the Luang Prabang Buffalo Dairy for their assistance and Four Seasons Company Pty Ltd. for donating and shipping the blocks to Laos.

Conflicts of Interest: The authors declare no conflict of interest. Although the Luang Prabang Buffalo Dairy and Four Seasons Pty Ltd. are commercial entities, this trial was conducted by donations of time and resources by all participants. The authors declare that the research was conducted 
independently from any commercial or financial relationships that could be construed as a potential conflict of interest.

\section{References}

1. FAO. World Livestock: Transforming the Livestock Sector through the Sustainable Development Goals; FAO: Rome, Italy, 2011; pp. xvi-xxxi. Available online: http:/ / www.fao.org/3/CA1201EN/ca1201en.pdf (accessed on 20 October 2020).

2. FAO. Mapping Supply and Demand for Animal-Source Foods to 2030. In Animal Production and Health Working Paper 2; FAO: Rome, Italy, 2018; Available online: https:/ / www.fao.org/3/i2425e/i2425e00.htm (accessed on 20 October 2020).

3. FAO. Livestock Systems: Buffaloes. 2020. Available online: http://www.fao.org/livestock-systems/global-distributions/ buffaloes/en/ (accessed on 15 July 2020).

4. Deb, G.K.; Nahar, T.N.; Duran, P.G.; Presicce, G.A. Safe and Sustainable Traditional Production: The Water Buffalo in Asia. Front. Environ. Sci. 2016, 4, 38. [CrossRef]

5. Bilal, M.Q.; Suleman, M.; Raziq, A. Buffalo: Black gold of Pakistan. Livest. Res. Rural Dev. 2006, 18, 128. Available online: http:/ / www.lrrd.org/lrrd18/9/bila18128.htm (accessed on 20 October 2020).

6. Nampanya, S.; Young, J.R.; Khounsy, S.; Bush, R.D.; Windsor, P.A. The food security challenge for the buffalo meat industry: Perspectives from Lao PDR. J. Buffalo Sci. 2014, 3, 38-47. [CrossRef]

7. Olmo, L.; Reichel, M.P.; Nampanya, S.; Khounsy, S.; Wahl, L.; Clarke, B.A.; Thomson, P.C.; Windsor, P.A.; Bush, R.D. Risk factors for Neospora caninum, bovine viral diarrhoea virus, and Leptospira interrogans serovar Hardjo infection in smallholder cattle and buffalo in Lao PDR. PLoS ONE 2019, 14, e0220335. [CrossRef] [PubMed]

8. Nampanya, S.; Khounsy, S.; Dhand, N.K.; Bush, R.D.; Windsor, P.A. Financial impact of an outbreak of clinically diagnosed Blackleg-A case study from Lao PDR. Veter. Med. Sci. 2019, 5, 118-128. [CrossRef] [PubMed]

9. Drake, D.J.; Nader, G.; Forero, L. Feeding Rice Straw to Cattle. In University of California, Division of Agriculture and Natural Resources. 2002. Available online: http://anrcatalog.ucanr.edu/pdf/8079.pdf. (accessed on 14 September 2019).

10. Fujita, Y.; Phanvilay, K. Land and forest allocation in Lao People's Democratic Republic: Comparison of case studies from community-based natural resource management research. Soc. Nat. Res. 2008, 21, 120-133. [CrossRef]

11. Matsumoto, N.; Nampanya, S.; Khounsy, S.; Young, J.R.; Ashley, K.A.; Bush, R.D.; Windsor, P.A. Challenges for beef production in smallholder communities with low reproductive management skills: A case study from Northern Lao PDR. Trop. Anim. Health Prod. 2017, 49, 87-96. [CrossRef] [PubMed]

12. FAO. Feed Supplementation Blocks. FAO Animal Production and Health Paper 164; Makkar, H.P.S., Sanchez, M., Speedy, A.W., Eds.; FAO: Rome, Italy, 2007; ISBN 978-92-5-105438-3.

13. Windsor, P.A.; Nampanya, S.; Kinnavong, B.; Phommasone, P.; Bush, R.D.; Khounsy, S. Do triclabendazole medicated molasses blocks have a role in control of Fasciola gigantica in smallholder cattle production in Lao PDR? Anim. Prod. Sci. 2019, 59, 787-793. [CrossRef]

14. Olmo, L.; Nampanya, S.; Nemanic, T.; Selwood, N.; Khounsy, S.; Young, J.R.; Thomson, P.C.; Bush, R.D.; Windsor, P.A. Can fenbendazole medicated molasses blocks control Toxocara vitulorum in smallholder cattle and buffalo calves in developing countries? Studies from upland Laos. Anim. Prod. Sci. 2020, 60, 2031-2043. [CrossRef]

15. Windsor, P.A.; Nampanya, S.; Olmo, L.; Khounsy, S.; Phengsavanh, P.; Bush, R.D. Provision of urea-molasses blocks to improve smallholder cattle weight gain during the late dry season in tropical developing countries. Studies from Lao PDR. Anim. Prod. Sci. 2020. [CrossRef]

16. Windsor, P.A.; MacPhillamy, I.; Khounsy, S.; Young, J.R.; Bush, R.D. Managing welfare and antimicrobial resistance issues in treating Foot-and-Mouth Disease lesions: A new therapeutic approach. Veter. Med. Res. Rep. 2020, 11, 99-107. [CrossRef] [PubMed]

17. Bates, D.; Maechler, M.; Bolker, B.; Walker, S. Fitting linear mixed-effects models using lme4. ArXiv 2014, arXiv:1406.5823.

18. Lenth, R. Emmeans: Estimated Marginal Means, Aka Least-Squares Means; R Package Version 1.4.7. 2020. Available online: https:/ /CRAN.R-project.org/package=emmeans (accessed on 15 September 2020).

19. Hothorn, T.; Bretz, F.; Westfall, P. Simultaneous inference in general parametric models. Biom. J. 2008, 50, 346-363. [CrossRef] [PubMed]

20. Dijkhuizen, A.A.; Morris, R.S. Animal Health Economics: Principles and Applications; Wageningen Press: Wageningen, The Netherlands, 1997; ISBN 13:978-0646314815.

21. Brar, P.S.; Nanda, A.S. Effect of supplementary feeding in improving reproductive performance in buffaloes. In Proceedings of the 9th International Congress on Biotechnology in Animal Reproduction (Management of Farm Animal Reproduction-Fertility Improvement and Advanced Technologies), Chenni, India, 20 October 2002; p. 271.

22. Phimmasone, K.; Douangpoutha, I.; Fauveau, V.; Pholsena, P. Nutritional Status of Children in the Lao PDR. J. Trop. Pediatr. 1996, 42, 5-11. [CrossRef] [PubMed]

23. Rasphone, S.; Fernandez, M. Every Stunted Child is Also Deprived in Three or More Areas of Well-Being; Press Release, Vientiane, UNICEF: New York, NY, USA, 2019; Available online: https:/ / www.unicef.org/laos/press-releases/every-stunted-child-alsodeprived-three-or-more-areas-well-being (accessed on 20 October 2020). 
24. Young, J.R.; Evans-Kocinski, S.; Bush, R.D.; Windsor, P.A. Improving smallholder farmer biosecurity in the Mekong region through change management. Transb. Emerg. Dis. 2015, 62, 491-504. [CrossRef] [PubMed]

25. Nampanya, S.; Khounsy, S.; Napsarith, V.; Bush, R.D.; Windsor, P.A. Smallholder large ruminant health and production in Lao PDR: Challenges and opportunities for improving domestic and regional beef supply. An. Prod. Sci. 2017, 57, $1001-1006$. [CrossRef] 